\title{
Determination of metallothionein in biological fluids using enzyme-linked immunoassay with commercial antibody
}

\author{
Halina Milnerowicz and Anna Bizoń凶 \\ Department of Biomedical and Environmental Analyses, Wrocław University of Medicine, Wroclaw, Poland
}

\begin{abstract}
Metallothionein (MT) is a low molecular weight cysteinerich protein with a number of roles in the pro/antioxidant balance and homeostasis of essential metals, such as zinc and copper, and in the detoxification of heavy metals, such as cadmium and mercury. Until now, detection of metallothionein in biological fluids remained difficult because of a lack of a broadly reactive commercial test. Meaningful comparison of the values of metallothionein concentrations reported by different authors using their specific isolation procedures and different conditions of enzyme-linked immunoassay is difficult due to the absence of a reference material for metallothionein. Therefore in the present study, we describe a quantitative assay for metallothionein in biological fluids such as plasma and urine performed by a direct enzymelinked immunoassay using a commercially available monoclonal mouse anti-metallothionein clone E9 antibody and commercial standards of metallothionein from rabbit liver and a custom preparation of metallothionein from human liver. The sensitivity of the assay for the standard containing two isoforms MT-I and MT-II from human liver was $140 \mathrm{pg} /$ well. The reactivity of the commercial standards and standards containing two isoforms MT-I and MT-II isolated from human liver in our laboratory with a commercial monoclonal mouse anti-metallothionein clone E9 antibody were similar. This suggests that the described ELISA test can be useful for determination of metallothionein concentration in biological fluids. The concentrations of metallothionein in human plasma, erythrocyte lysate and in urine of smoking and non-smoking healthy volunteers are reported. Tobacco smoking increases the extracellular metallothionein concentration (plasma and urine) but does not affect the intracellular concentration (erythrocyte lysate).
\end{abstract}

Keywords: metallothionein MT-I and MT-II, ELISA, human biological fluids

Received: 23 November, 2009; revised: 16 March, 2010; accepted: 20 March, 2010; available on-line: 22 March, 2010

\section{INTRODUCTION}

Metallothionein (MT) is a low molecular weight cysteine-rich protein affecting the redox balance and homeostasis of essential metals, such as zinc and copper, and crucial in the detoxification of heavy metals, such as cadmium and mercury (Bremner et al., 1990; Lynes et al., 2006). MT synthesis is induced by various stimuli such as oxidative stress, heavy metals, glucocorticoids, and cytokines (Viarengo et al., 2000). There are two major isoforms of this protein - isoform I (MT-I) and isoform
II (MT-II), which are expressed in most tissues and stages of development (Klaassen et al., 1999). MT has been found in both extracellular spaces and in intracellular compartments (Lynes et al., 2006). Immunohistochemical studies have revealed the protein also in the nucleus and, at very low concentrations, in extracellular fluids such as plasma, bile and urine (Akintola et al., 1995).

Identification, quantification and structural characterization of MTs is crucial for the determination of the roles played by these metalloproteins in the organism (Dabrio et al., 2002). Quantification of MT in body fluids may be useful as a biological indicator of the exposure of individuals to the mentioned earlier factors.

Methods for quantification of MT are based on a direct determination of the peptide moiety of MT or an indirect determination via the metal and $\mathrm{SH}$ content of MT (Summer \& Klein, 1991). However, no commercial test for quantification of MT in biological fluids is yet available (Dabrio et al., 2002).

Enzyme-linked immunoassay (ELISA) can be used to measure the concentration of metallothionein in biological fluids. There are two kinds of ELISA procedures: competitive ELISA (cELISA) and direct ELISA. cELISA methods for MT-I were developed using prepared a custom antibodies (Grider et al., 1989; Akintola et al., 1995). A direct ELISA procedure employing a commercial monoclonal anti-MT antibody for use with filtered urine has also been reported (Hirauchi et al., 1999).

In the present study, we describe a quantitative direct ELISA assay for MT in biological fluids such as plasma, erythrocyte lysate and urine using a commercially available monoclonal mouse anti-metallothionein clone E9 antibody (Dako) and a commercial standard containing MT-I or MT-II from rabbit liver (Sigma-Aldrich). We also compare results obtained for the commercial metallothionein standard with those for metallothionein isolated from human liver in our laboratory.

\section{MATERIALS AND METHODS}

Preparation of metallothionein from human liver. Preparation of metallothionein was performed at $4{ }^{\circ} \mathrm{C}$. Metallothionein was isolated from human liver according to the method described by Hidalgo et al. (1989).

Me-mail: a_bizon@op.pl

Abbreviations: cELISA, competitive enzyme-linked immunoassay; ELISA, enzyme-linked immunoassay; MT, metallothionein; MT-I, isoform I of metallothionein; MT-II, isoform II of metallothionein; PVDF, polyvinylidene fluoride; SDS/PAGE, polyacrylamide gel electrophoresis 
Liver from a 40-years man who died in an accident was collected during autopsy at the Department of Pathomorphology, Wroclaw Medical University. The study protocol was approved by the Local Bioethics Committee (KB No 165/1999). Pieces of liver were washed several times in phosphate-buffered salne (PBS), minced and $20 \mathrm{~g}$ of liver was homogenized with $82 \mathrm{ml}$ of buffer containing $10 \mathrm{mM}$ Tris $/ \mathrm{HCl}, \mathrm{pH} 8.6$, with $10 \mathrm{mM}$ 2-mercaptoethanol (Sigma-Aldrich, ref. No M6259, Germany) and $25 \mathrm{mM}$ sucrose (Sigma-Aldrich, ref. No 84097, Germany) using a Potter-Elvehjem homogenizer at $4{ }^{\circ} \mathrm{C}$. The homogenate $(100 \mathrm{ml})$ was centrifuged immediately at $5000 \times g$ for $25 \mathrm{~min}$ at $4{ }^{\circ} \mathrm{C}$ then centrifuged for $1 \mathrm{~h}$ at $10000 \times g$. Supernatant $(72 \mathrm{ml})$ was collected and centrifuged for $2 \mathrm{~h}$ at $105000 \times g$ at $4{ }^{\circ} \mathrm{C}$ (Sorvall Ultra 80 Combi Plus). To the obtained cytosol fraction, $\mathrm{CdCl}_{2}$ (99, 999\%, Sigma Aldrich, ref. No 4398000, Germany) $1 \mathrm{mg} / \mathrm{ml}$ was added to a final concentration of 25 $\mu \mathrm{g} \mathrm{CdCl} / 1 \mathrm{ml}$ of cytosol during incubation in a water bath at $80^{\circ} \mathrm{C}$ for $10 \mathrm{~min}$ with stirring. The presence of 2-mercaptoethanol and cadmium assures that MT is not oxidized (Hidalgo et al., 1989). From $69 \mathrm{ml}$ of the cytosol fraction, proteins were precipitated with acetone (to $60 \%$ ) and centrifuged. The pellet was discarded and the supernatant was brought to $80 \%$ acetone and the proteins were allowed to precipitate overnight at $4{ }^{\circ} \mathrm{C}$ then centrifuged for $1 \mathrm{~h}$ at $10000 \times \mathrm{g}$. The proteins pellet were dissolved in $7.5 \mathrm{ml}$ of $10 \mathrm{mM}$ Tris/ $\mathrm{HCl}, \mathrm{pH} 8.6$, centrifuged and the final supernatant was stored at $-80^{\circ} \mathrm{C}$. A sample of $6.7 \mathrm{ml}$ containing $2.15 \mathrm{mg}$ of protein $/ \mathrm{ml}$ was applied onto a Sephadex G-75 (Sigma Aldrich, ref. No G75120, Germany) column $(2.6 \mathrm{~cm} \times 120 \mathrm{~cm})$ equilibrated with $10 \mathrm{mM}$ Tris/ $\mathrm{HCl}, \mathrm{pH}$ 8.6. The column was run in $10 \mathrm{mM}$ Tris $/ \mathrm{HCl}, \mathrm{pH} 8.6$, at a flow rate of 12 $\mathrm{ml} / \mathrm{h}$ at $4^{\circ} \mathrm{C}$ and $3-\mathrm{ml}$ fractions were collected.

Absorbance at $\lambda=220,250 \mathrm{~nm}$ and $280 \mathrm{~nm}$ was monitored. Fractions with the OD 250/280 ratio from 7.4 to 9 were combined and applied without prior concentration on a DEAE-cellulose (DE-52) column (2.6 $\mathrm{cm} \times 120 \mathrm{~cm}$ ) equilibrated with $10 \mathrm{mM}$ Tris $/ \mathrm{HCl}, \mathrm{pH}$ 8.6. Elution was done with a linear gradient of 20-200 $\mathrm{mM}$ Tris/ $\mathrm{HCl}, \mathrm{pH} 8.6$, at a flow rate of $30 \mathrm{ml} / \mathrm{h}$. Two peaks corresponding, respectively, to MT-I and MTII were obtained. Absorbance at 220, 250 and $280 \mathrm{~nm}$ was measured and the fractions with a high absorbance at 220 and $250 \mathrm{~nm}$ were collected and concentrated using a YM3 membrane (Amicon Ultra-15 Centrifugal Filter Unit with Ultracel-3 membrane, Millipore, ref. No UFC9-003, USA).

The molecular mass of MT standards was determined by gel filtration on a Sephadex G-75 column (2.6 $\mathrm{cm} \times 120 \mathrm{~cm}$ ) equilibrated with $10 \mathrm{mM}$ Tris $/ \mathrm{HCl}, \mathrm{pH}$ 8.6 and by SDS/PAGE (Aoki \& Suzuki, 1991).

Identification of MT isoforms by SDS/PAGE and Western blotting. Samples containing isoforms of MT were dissolved in $50 \mathrm{mM}$ Tris $/ \mathrm{HCl}, \mathrm{pH} 6.8,10 \%$ glycerol, 2\% SDS (Sigma-Aldrich, ref. No L3771, Germany), $2.5 \mathrm{mM}$ 2-mercaptoethanol (Bio-Rad, ref. No 1610710, USA) and $0.05 \%$ bromophenol blue (Sigma-Aldrich, ref. No B0126, Germany). Protein concentration was determined by the Bradford method (Bradford, 1976). The samples were heated in a water bath at $95^{\circ} \mathrm{C}$ for $3 \mathrm{~min}$. Sodium dodecyl sulfate $/ 15 \%$ polyacrylamide gel electrophoresis (SDS/PAGE 15\%) was performed according to the method described by Aoki and Suzuki (1991). Electrophoresis was performed for $2 \mathrm{~h}$.

Gels were stained with Dodeca Silver Stain Kit (BioRad, ref. No 1610481, USA). After staining the ratio of MT-I and MT-II isoforms was determinate using a Gel
Analysis Software (Quantity One 1-D Analysis Software, Bio-Rad ref. No 170-9600, USA). For Western blotting, proteins from gel were transferred to a polyvinylidene fluoride membrane (PVDF, Sequi-Blot PVDF Membrane Bio-Rad, ref. No 162-0236, USA) using a MiniPROTEAN Tetra Cell Electrophoresis Module (BioRad, ref. No 165800, USA) and Mini Trans-Blot Module (Bio-Rad, ref. No 1703930, USA) according to the methods previously described (Aoki \& Suzuki 1991).

The PVDF membrane was stained using Ponceau S (Sigma-Aldrich ref. No P3504, Germany). To block nonspecific binding, the membrane was preincubated with TTBS (Tris-buffered saline, $\mathrm{pH}$ 7.6, containing $0.05 \%$ Tween-20 and 5\% nonfat milk) (Skrzycki et al., 2009), then was incubated overnight at $4{ }^{\circ} \mathrm{C}$ with a monoclonal mouse anti-metallothionein clone E9 antibody (DakoCytomation, ref. No M0639, Denmark) diluted 1:200 in Tris-buffered saline, $\mathrm{pH}$ 7.6, containing $0.05 \%$ Tween-20. The membrane was washed and incubated for $1 \mathrm{~h}$ at room temperature with alkaline phosphatase-conjugated goat anti-mouse antibody diluted 1:1000 in Tris-buffered saline, $\mathrm{pH} 7.6$, containing $0.05 \%$ Tween-20 (GAM-AP, ref. No 85873, Bio-Rad, USA). The color reaction was visualized using a commercial kit (AP Conjugate Substrate Kit, Bio-Rad, ref. No 1706432, USA).

Enzyme-linked immunosorbent assay. The twostep direct ELISA using a commercial MT standard (Sigma-Aldrich, ref. No M7641, Germany) according to the procedure described by Hirauchi et al. (1999). A dilution series of MT was performed from 1 to $100 \mathrm{ng} / \mathrm{ml}$ (100 $\mu \mathrm{l})$ in $50 \mathrm{mM}$ Tris-25 mM HCl or $100 \mu \mathrm{l}$ of biological samples (plasma, urine or erythrocyte lysate) were incubated in microtiter plates overnight at $4{ }^{\circ} \mathrm{C}$. After incubation, the wells were washed three times using wash buffer containing $40 \mathrm{mM}$ Tris-33 mM HCl with $154 \mathrm{mM} \mathrm{NaCl}$ and $0.05 \%(\mathrm{w} / \mathrm{v})$ Triton X-100 (Sigma-Aldrich, ref. No $\mathrm{X} 100$, Germany). The microplate was then blocked using a buffer containing 3\% (w/v) gelatin (Bio-Rad, ref. No 170-6537, USA) in $40 \mathrm{mM}$ Tris-20 $\mathrm{mM} \mathrm{HCl}$ with 154 $\mathrm{mM} \mathrm{NaCl}$ and $0.05 \%(\mathrm{w} / \mathrm{v})$ Triton X-100 (300 $\mu \mathrm{l})$, and incubated for $1 \mathrm{~h}$ at $25^{\circ} \mathrm{C}$. After washing, primary monoclonal mouse metallothionein Clone E-9 antibody (Dako, ref. No M0639, Denmark) was added in a 1:20 dilution in a buffer containing $1 \%(\mathrm{w} / \mathrm{v})$ gelatin in $40 \mathrm{mM}$ Tris$33 \mathrm{mM} \mathrm{HCl}$ with $154 \mathrm{mM} \mathrm{NaCl}$ and $0.05 \%$ (w/v) Triton X-100 $(100 \mu \mathrm{l})$ and incubated overnight at $25^{\circ} \mathrm{C}$. The wells were washed three times using wash buffer containing $40 \mathrm{mM}$ Tris-33 $\mathrm{mM} \mathrm{HCl}$ with $154 \mathrm{mM} \mathrm{NaCl}$ and $0.05 \%$ (w/v) Triton X-100. The secondary biotinylated polyclonal goat anti-mouse IgG antibody (Dako, ref. No E0433, Denmark) was then added in a 1:400 dilution in buffer containing $1 \%(\mathrm{w} / \mathrm{v})$ gelatin in $40 \mathrm{mM}$ Tris-33 $\mathrm{mM} \mathrm{HCl}$ with $154 \mathrm{mM} \mathrm{NaCl}$ and $0.05 \%$ (w/v) Triton X-100 $(100 \mu \mathrm{l})$ and incubated for $4 \mathrm{~h}$ at $25^{\circ} \mathrm{C}$. The wells were then washed three times and incubated for $1 \mathrm{~h}$ at $25^{\circ} \mathrm{C}$ with HRP-Avidin (Dako, ref. No P0347, Denmark) diluted 1:800 in buffer containing $1 \%(\mathrm{w} / \mathrm{v})$ gelatin in $40 \mathrm{mM}$ Tris-33 mM HCl with $154 \mathrm{mM} \mathrm{NaCl}$ and $0.05 \%$ $(\mathrm{w} / \mathrm{v})$ Triton X-100 $(100 \mu \mathrm{l})$. The reaction was visualized by ortophenylenediamine in $200 \mu \mathrm{l}$ of $0.25 \mathrm{M}$ phosphate citrate buffer (citric acid, Sigma-Aldrich, ref. No 251275, Germany; sodium phosphate dibasic, Sigma-Aldrich, ref. No S7907, Germany), pH 5.5 containing $0.006 \% \mathrm{H}_{2} \mathrm{O}_{2}$. The color reaction was stopped using $50 \mu \mathrm{l}$ of $3 \mathrm{M} \mathrm{HCl}$. The absorbance was measured at $490 \mathrm{~nm}$ in an ELISA reader (STAT-FAX 2100, Analco, USA). Using the elaborated conditions, concentrations of metallothionein were determined by linear regression of a standard curve after 
$\log$ transformation. The sensitivity of the ELISA for a sample containing isoforms MT-I or MT-II was found to be $140 \mathrm{pg} /$ well.

We compared the affinity of the commercial monoclonal mouse anti-metallothionein clone E9 antibody to the commercial standards of MT I (Sigma-Aldrich, ref. No M5267, Germany) or MT II (Sigma-Aldrich, ref. No M5392, Germany) isolated from rabbit liver and a standard containing two isoforms MT-I and MT-II or only MT-I isolated from human liver in our laboratory.

Analytical procedure. The concentration of MT was measured in plasma, erythrocyte lysate and urine. Blood and urine from 45 men were assayed: 17 smoking (aged $40.8 \pm 10.4$ years) and 28 non-smoking (aged 41.3 \pm 6.7 years). The study protocol was approved by the Local Bioethics Committee of Wroclaw Medical University (KB No 94/2007).

Whole blood was drawn into trace element-free tubes containing heparin and centrifuged at $2500 \times g$ for $15 \mathrm{~min}$ to separate the plasma from cell pellet. The pellet was washed in equal volume of ice-cold $0.9 \% \mathrm{NaCl}$. This process was repeated twice. The washed cells were lysed by addition of ice-cold, double distilled water (Hydrolab, HLP Smart 1000, Poland) $(1: 1.4)$, and the resulting lysate was used for the ELISA (Thomas et al., 1992). Plasma and the erythrocyte lysates were frozen at $-80^{\circ} \mathrm{C}$ until used. Protein concentration was determined by the Lowry method (Lowry et al., 1951).

Spot urine samples were collected in acid-washed containers and stored at $-80^{\circ} \mathrm{C}$ until required for analysis. Urinary creatinine levels were determined by the Jaffe reaction (Butler, 1975).

Statistical analysis. The data are expressed as mean \pm S.D. values. The normality of the variable was tested by the Shapiro-Wilk $W$ test. Differences between the smoking and non-smoking groups were tested using Student's $t$-test. In all instances, $P<0.05$ was considered as statistically significant. Statistical calculations were done using STATISTICA version 6.0 (Polish version; StatSoft, Kraków, Poland).

\section{RESULTS}

MT was purified from human liver by Sephadex G-75 chromatography and the absorbance was measured at $\lambda=220 \mathrm{~nm}, \lambda=250 \mathrm{~nm}$ and $\lambda=280 \mathrm{~nm}$. As expected, the low molecular-weight protein peak showed a high absorbance at $250 \mathrm{~nm}$, a feature indicating the binding of cadmium to MT. The low absorbance at $280 \mathrm{~nm}$ confirmed a lack of aromatic amino acids, as it had already been shown for MT from various species (Hidalgo et al., 1989). The $250 / 280$ absorbance ratio for the MT peak of the gel filtration chromatography was from 7.4 to 9 in collected fractions. We assayed for sulfhydryl groups with the Ellmann method in collected fractions (Ellman, 1959). The result confirmed the presence of numerous sulfhydryl groups in our samples. The molecular mass determined by gels filtration was about $8 \mathrm{kDa}$. Determination of the molecular mass using ProteomeLab ${ }^{\mathrm{TM}}$ SDS-MW Analysis Kit (Beckamn Coulter, ref. No P/N 390963AB, USA) on capillary electrophoresis (ProteomeLab ${ }^{\text {TM }}$ PA 800, Beckman-Coultur) confirmed the presence of a pure protein with molecular mass of about $9 \mathrm{kDa}$ (unpublished), in agreement with earlier results of Kriskova et al. (2009).

Separation of human MT by DEAE-cellulose (DE-52) ion-exchange chromatography gave two major peaks of high $\mathrm{Cd}$ content representing metallothionein isoforms
MT-I and MT-II. The separation was based on their single charge difference. The presence of the metallothionein isoforms and the molecular mass were confirmed by polyacrylamide gel electrophoresis and Western blotting. The detection limit of SDS/PAGE silver staining was about $100 \mathrm{ng} /$ lane. The results highligheted two important points: the isoforms could separated by SDS/ PAGE and metallothionein stains strongly using silver. Metallothionein is substantially more enhanced by silver staining than are other low-molecular-mass, heat stable proteins (McCormick \& Lin, 1991).

We analyzed the ratio of MT isoforms I and II using commercial Quantity One 1-D Analysis Software. The results showed that MT-I constituted approx. $75 \%$ of the total amount of metallothionein.

Figure 1 shows a gel after silver staining and PVDF membrane after Ponceau S staining. The presence of metallothionein in samples was confirmed by Western blotting analysis using a monoclonal antibody against MT, Clone E-9 (DakoCytomation, ref. No M0639, Denmark). The results are shown in Fig. 2. The obtained image also confirms the presence of two isoforms, MT-I and MT-II, in our samples.

We compared the affinity of different isoforms (MT-I and MT-II) of metallothionein to the commercial antibody by direct ELISA analyses performed in the same experimental conditions. We analyzed the commercial standard and samples isolated in our laboratory containing two isoforms, MT-I and MT-II and those containing only one isoform, MT-I or MT-II. There were slight differences in the affinity of the commercial monoclonal mouse anti-metallothionein clone E9 antibody to samples containing different isoforms of MT isolated from human liver or from rabbit liver (Fig. 3).

We assayed the concentration of MT in erythrocyte lysate, plasma and urine of smoking and non-smoking healthy men using the elaborated ELISA procedure. We observed a significantly higher concentration of MT in the plasma and urine of smokers. In contrast, the concentration of metallothionein in erythrocyte lysates was similar in the two groups. The results are shown in Table 1.

\section{DISCUSSION}

The quantification of MT is challenging and has led to the development of various techniques for that purpose.

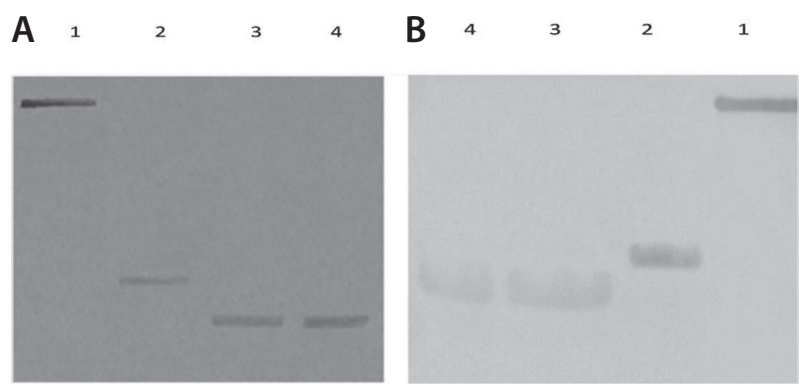

Figure 1. Localization of metallothionein

(A) SDS/PAGE electrophoresis, silver staining (amount of proteins about $100 \mathrm{ng} / \mathrm{lane}$ ). (B) PVDF membrane staining with Ponceau $\mathrm{S}$ (amount of proteins about $20 \mu \mathrm{g} / \mathrm{lane}$ ). (1) Albumin human electrophoretic marker + vitamin B12, molecular weight $67 \mathrm{kDa}$, (Serva, ref. No. 11885, Germany), (2) myoglobin from human heart, molecular mass 17 kDa (Sigma-Aldrich, ref. No M0636, USA); (3-4) samples containing two isoforms of MT from human liver, molecular mass approx. 6.5 kDa. 


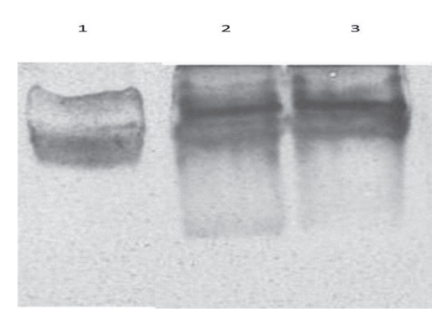

Figure 2. Western blot analysis of purified human hepatic MT-I and MT-2.

After separation by SDS/PAGE proteins were transferred on PVDF membrane. The presence of MT was visualized using commercial monoclonal mouse anti-metallothionein clone E9 antibody. Commercial standard of MT-II from rabbit (2-3) samples containing two isoforms of MT isolated in our laboratory from human liver.

Changes in MT concentration have been observed in various diseases, therefore MT quantification may be a useful indicator of pathologic states, which calls for a convenient procedure for quantitative analysis of MT (Andrews, 2000). The sensitivity of immunoassay primarily depends on the specificity and affinity of the antibody, therefore the type of antibody is crucial for ELISA assay. The reproducibility of ELISA assays using antibodies purified in different laboratories is not always satisfactory because the availability of the antibodies is limited (Dabrio et al., 2002). In many studies MT isolated from different mammalian tissues, containing variable ratios of MT isoforms, was used as a standard. Different authors have elaborated specific procedures in each laboratory. Therefore a robust comparison of the results of MT quantification with the use of different standards, antibodies and different conditions of ELISA is virtually imposible.

The large number of isoforms and subisoforms within the MT family makes application of immunological techniques to biological fluids difficult. In order to increase the selectivity and sensitivity of these methods, the specificity of the antibodies is important. However, the entire MT family lacks common antibodies for the different isoforms and subisoforms, which could result in underestimation when total MT is measured, for example by ELISA (Dabrio et al., 2002).

Hirauchi et al. (1999) have elaborated a direct ELISA procedure using commercial reagents but the biological fluids were filtered using a microcentrifuge tube with a filter.

The purpose of this report was to elaborated an ELISA procedure using commercial standard and antibody without any specific preparation of samples.

In our earlier studies we assayed the concentrations of MT in human milk and fluid collected intrasurgically

Table 1. Metallothionein concentrations in blood and in urine of smoking and non-smoking healthy volunteers

\begin{tabular}{llll}
\hline \multicolumn{4}{l}{ Concentration of metallothionein in biological fluids } \\
\hline $\begin{array}{l}\text { Healthy volunteers } \\
\mathrm{n}=35\end{array}$ & $\begin{array}{l}\text { plasma } \\
(\mathrm{ng} / \mathrm{ml})\end{array}$ & $\begin{array}{l}\text { erythrocyte lysate } \\
(\mu \mathrm{g} \text { MT/g of protein) }\end{array}$ & $\begin{array}{l}\text { urine } \\
(\mu \mathrm{g} \text { MT/g of creatinine) }\end{array}$ \\
$\begin{array}{l}\text { smoking } \\
\mathrm{n}=17\end{array}$ & $4.40 \pm 2.76^{*}$ & $14.70 \pm 4.05$ & $1.47 \pm 0.99^{* *}$ \\
$\begin{array}{l}\text { non-smoking } \\
\mathrm{n}=28\end{array}$ & $3.42 \pm 2.30^{*}$ & $14.42 \pm 2.39$ & $1.08 \pm 0.46^{* *}$ \\
\hline
\end{tabular}

* Statistically significant differences for metallothionein in plasma between smoking and non-smoking groups, $P<0.02 ;{ }^{*}$ Statistically significant differences for metallothionein in urine between smoking and non-smoking groups, $P<0.04$. Values are expressed as $X \pm S . D$.

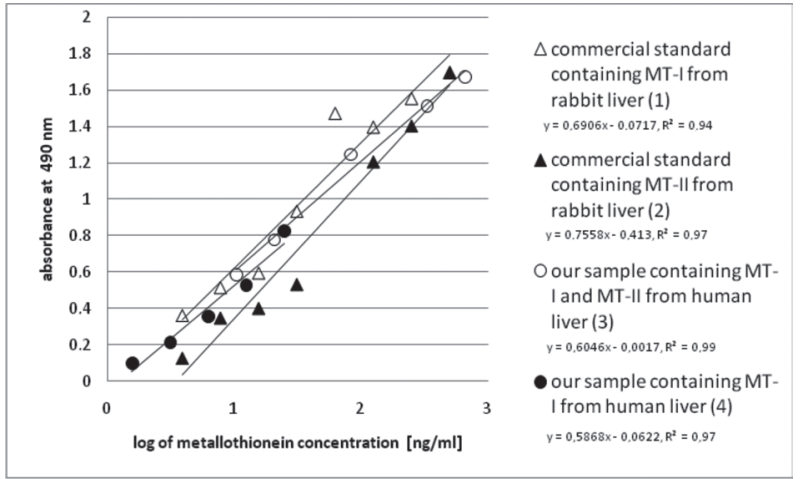

Figure 3. Comparison of standard curves obtained for different isoforms of MT.

Direct ELISA two step assay was run with commercial anti-MT antibody Clone E-9.

from pancreatic cysts of patients with chronic pancreatitis using a ${ }^{109} \mathrm{cadmium} /$ haemoglobin assay. The level of MT in breast milk of smoking women was $5.1 \pm 1.9 \mu \mathrm{g} /$ $\mathrm{ml}$ (Milnerowicz \& Chmarek, 2005) and 13.8 $\pm 3.3 \mu \mathrm{g} /$ $\mathrm{ml}$ in fluids collected intrasurgically from pancreatic cysts of patients with acute or chronic pancreatitis (Milnerowicz et al., 2004). Those values of MT concentrations were many times higher than the concentrations of MT in the plasma or urine (Akintola et al., 1995), therefore quantification of MT in plasma and urine using those methods is impossible. In the present study we used a two-step direct ELISA assay with commercial standard and antibodies. We compared the affinity of commercial monoclonal antibodies to different isoforms of MT isolated from human or rabbit liver using this ELISA assay. We used MT-I and MT-II isoforms because there were recent reports that the MT-III and MT-IV isoforms were tissue-specific, MT-III was specifically expressed in the brain and MT-IV was expressed only in differentiating cells of stratified squamous epithelia, and presence of MT-III and MT-IV in the plasma or serum has not yet been demonstrated (Palimter et al., 1992; Quaife et al., 1994). Our investigation showed only a slight difference in the affinity of the commercial MT antibody to samples containing different isoforms of MT isolated from human liver and rabbit liver. The reactivity of the commercial standard of metallothionein and metallothionein isolated in our laboratory suggests that the described ELISA procedure can be useful for researchers who need a simple tool to determine of metallothionein concentration in biological fluids.

Immunological studies using rabbit polyclonal antibody and murine monoclonal antibodies raised against rat MT showed that they were cross-reactive with various kinds of mammalian MTs (Nakajima et al., 1991). In a sensitive competitive radioimmunoassay for MT using both polyclonal and monoclonal antibodies, full cross-reactivity was observed for MT isolated from the livers of rat, rabbit and human (Nakajima et al., 1991). Our method was also used to determine the concentrations of MT in the plasma, erythrocyte lysate and urine in 
smoking and non-smoking healthy volunteers. Whole blood was drawn on heparin, because earlier study was shown, that addition of EDTA displaced heavy metals from MTs and renders them susceptible to tryptic digestion (Wang et al., 2007). In all cases the concentrations of MT in the blood and urine were higher in smokers than in non-smokers. The highest concentrations of MT were found in erythrocyte lysate of smoking (14.70 \pm 4.05 $\mu \mathrm{g} / \mathrm{g}$ of protein) and non-smoking $(14.42 \pm 2.39 \mu \mathrm{g} / \mathrm{g}$ of protein) healthy volunteers.

The concentration of MT in the plasma of smokers was statistically significantly increased $(4.40 \pm 2.76 \mathrm{ng} /$ $\mathrm{ml}, P<0.02)$ in comparison to non-smokers $(3.42 \pm 2.30$ $\mathrm{ng} / \mathrm{ml})$. The increase of MT concentration in plasma suggests induction of the synthesis of MT in the liver and confirms the circulation of the MT-cadmium complex from liver to kidney (Park et al., 2001, Nordberg, 2009). In the urine of smoking, healthy volunteers the concentration of MT was also increased $(1.47 \pm 0.9 \mu \mathrm{g} / \mathrm{g}$ of creatinine, $P<0.04)$ compared with non-smokers $(1.08 \pm 0.46 \mu \mathrm{g} / \mathrm{g}$ of creatinine). The increase of MT concentration in urine of healthy smokers persons confirms the accumulation of cadmium in the kidney and nephrotoxicity of cadmium deriving from tobacco smoking (Ronco et al., 2005). The obtained results show that tobacco smoking in healthy persons influences extracellular MT concentration (plasma and urine) but does not change the intracellular MT concentration (erythrocyte lysate).

Akintola et al. (1995) developed an ELISA assay for measuring MT-I in plasma and urine. The mean concentrations of MT-I in plasma and urine in man were $32 \pm 16 \mathrm{ng} / \mathrm{ml}$ and $10 \pm 6 \mathrm{ng} \mathrm{MT}-\mathrm{I} / \mu \mathrm{mol}$ of creatinine, respectively. Investigations performed by Nordberg et al. (1982) using radioimmunoassay showed that MT concentrations in plasma and urine ranged between $2-11.3 \mathrm{ng} / \mathrm{g}$ of protein and $2-155.2 \mathrm{ng} / \mathrm{g}$ of protein, respectively. MT levels were measured by a two-step competitive ELISA procedure in urine of two groups of children living in areas of mild and high environmental pollution due mainly to heavy metals (Swierzcek et al., 2004). The MT concentrations in that study ranged between 3-30 $\mu \mathrm{g} / \mathrm{g}$ of creatinine. Grider et al. measured MT concentrations in erythrocyte lysate using human MT-I as a standard in a competitive ELISA assay. The MT concentrations was $34 \pm 6 \mu \mathrm{g} / \mathrm{g}$ of protein (Grider et al., 1989). However, a reliable comparison of the results of MT quantification obtained by different authors using their specific isolation procedures and various types of ELISA assay is not easy due to the absence of a reference material for MT.

\section{CONCLUSIONS}

Our investigation showed similar affinity of commercial monoclonal mouse anti-metallothionein clone E9 antibody to MT-I and MT-II isoforms isolated from human and rabbit liver.

The similar affinity of isofoms MT-I and MT-II to the antibody ensures accurate determination of total MT concentration regardless of the proportion of the MT isoforms in biological samples.

The detection limit $(140 \mathrm{pg} / 100 \mu \mathrm{l})$ of this ELISA procedure using commercial reagents allows determination of the concentration of metallothionein in biological fluids such as plasma, urine and erythrocyte lysate without any specific pretreatment.

Tobacco smoking in healthy persons increases extracellular metallothionein concentration (plasma and urine) but does not change intracellular metallothionein concentration (erythrocyte lysate).

\section{Acknowledgements}

This research was supported by the State Committee of Scientific Research, Poland (grant No 0552/B/ P01/2009/36).

\section{REFERENCES}

Akintola DF, Sampson B, Fleck A (1995) Development of an enzymelinked immunosorbent assay for human metallothionein-1 in plasma and urine. J Lab Clin Med 126: 119-127.

Andrews GK (2000) Regulation of metallothionein gene expression by oxidative stress and metal ions. Biochem Pharmacol 59: 95-105.

Aoki Y, Suzuki KT (1991) Detection of metallothionein by Western blotting. Methods Ensymol 205: 108-114.

Bradford MM (1976) Rapid and sensitive method for the quantitation of microgram quantities of protein utilizing the principle of proteindye binding. Anal Biochem 72: 248-254.

Bremner I, Beattie JH (1990) Metallothionein and the trace minerals. Annu Rev Nutr 10: 63-83.

Butler AR (1975) The Jaffe reaction. Identification of the coloured species. Clin Chim Acta 10: 227-232.

Dabrio M, Rodriquez AR, Bordin G, Bebianno MJ, Ley MD, Sestakova I, Vasak M, Nordberg M (2002) Recent developments in quantification methods for metallothionein. J Inorg Biochem 88: 123-134.

Ellman GL (1959) Tissue sulfhydryl groups. Arch Biochem Biophys 82: $70-77$.

Grider A, Kao KJ, Klein PA, Cousins RJ (1989) Enzyme-linked immunosorbent assay for human metallothionein: correlation of induction with infection. J Lab Clin Med 113: 221-228.

Hidalgo J, Dingman A, Garvey JS (1989) Preparative isolation of adult human liver metallothionein isoforms. Rev Espanola Fisiol 45: 255264.

Hirauchi T, Okabe M, Nagashima T, Niioka T (1999) Metallothionein quantitation in biological materials by enzyme-linked immunosorbent assay (ELISA) using a commercial monoclonal antibody. Trace Elem Electrolytes 16: 177-182.

Klaassen CD, Liu J, Chaudhuri S (1999) Metallothionein: an intracellular protein to protect against cadmium toxicity. Ann Rev Pharmacol Toxicol 39: 267-294.

Krizkova S, Adam V, Kizek R (2009) Study of metallothionein oxidation by using of chip CE. Electrophoresis 30: 4029-4033.

Lowry OH, Rosebrough NJ, Farr AL, Randall RJ (1951) Protein measurement with the Folin phenol reagent. J Biol Chem 193: 265-275.

Lynes MA, Zaffuto K, Unfricht DW, Marusov G, Samson JS, Yin X (2006) The physiological roles of extracellular metallothionein. Exp Biol Med 231: 1548-1554.

McCormick CC, Lin LY (1991) Quantification and identification of metallothionein by gel electrophoresis and silver staining. Methods Enzymol 205: 71-78.

Milnerowicz H, Chmarek M, Bukowski R, Milnerowicz S (2004) The concentration of metallothionein in fluid collected intrasurgically from pancreatic cysts of patients with diseases of the pancreas. Farmacja - tradycja i nowoczesność (Suppl. 2), SXIV-P018 (in Polish).

Milnerowicz H, Chmarek M (2005) Influence of smoking on metallothionein level and other proteins binding essential metals in human milk. Acta Paediatr 94: 402-406.

Nakajima K, Suzuki K, Otaki N, Kimura M (1991) Epitope map ping of metallothionein antibodies. Methods Ensymol 205: 174-189.

Nordberg GF (2009) Historical perspectives on cadmium toxicology. Toxicol Appl Pharmacol 238: 192-200.

Nordberg GF, Garvey JS, Chang CC (1982) Metallothionein in plasma and urine of cadmium workers. Environ Res 28: 179-182.

Palmiter RD, Findley SD, Whitmore TE, Durnam DM (1992) MT-III, a brain-specific member of the metallothionein gene family. Proc Natl Acad Sci USA 89: 6333-6337.

Park JD, Liu Y, Klaassen CD (2001) Protective effect of metallothionein against toxicity of cadmium ant other metals. Toxicology 163: 93-100.

Quaife CJ, Findley SD, Erickson JC, Froelick GJ, Kelly EJ, Zambrowicz BP, Palmiter RD (1994) Induction of a new metallothionein isoform (MT-IV) occurs during differentiation of stratified squamous epithelia. Biochemistry 33: 750-759.

Ronco AM, Arguello G, Suazo M, Llanos MN (2005) Increased levels of metallothionein in placenta of smokers. Toxicology 208: 133-139.

Skrzycki M, Majewska M, Podsiad M, Czeczot H (2009) Expression and activity of superoxide dismutase isoenzymes in colorectal cancer. Acta Biochim Pol 56: 663-670. 
Summer KH, Klein D (1991) Determination of metallothionein in biological materials. Methods Enzymol 205: 57-60.

Swierzcek S, Abuknesha RA, Chivers I, Baranovska I, Cunningham P, Price RG (2004) Enzyme-immunoassay for the determination of metallothionein in human urine: application to environmental monitoring. Biomarkers 9: 331-340.

Thomas EA, Bailey LB, Kauwell GA, Lee DY, Cousins RJ (1992) Erythrocyte metallothionein response to dietary zinc in humans. J Nutr 122: 2408-2414.
Viarengo A, Burlando B, Ceratto N, Panfoli I (2000) Antioxidant role of metallothioneins: a comparative overview. Cell Mol Biol 46: 407417.

Wang R, Sens D, Albrecht A, Garrett S, Somii S, Sens MA, Lu X (2007) Simple methods for identification of metallothionein isoforms in cultured human prostate cells by MALDI-TOF/TOF spectrometry. Anal Chem 79: 4433-4441. 